\title{
A Conceptual Review of Social Infrastructure Projects
}

\author{
Wai Soon $\mathrm{Han}^{1}$, Aminah Md Yusof ${ }^{1}$, Tey Kim Hai ${ }^{1}$ and Syuhaida Ismail ${ }^{2}$ \\ ${ }^{1}$ Faculty of Civil Engineering, University of Technology Malaysia, Malaysia \\ ${ }^{2}$ University of Technology Malaysia International Campus, Kuala Lumpur, Malaysia
}

\begin{abstract}
Social infrastructure projects (SIP), as the name implies, is defined as those buildings, structures and facilities specifically constructed to serve the community at large. The most apparent form of the social infrastructure projects are hospitals, schools and community facilities. Consequently, the nature of the infrastructure attracts less attention. In a sense, social infrastructure projects are one of the main criteria to enhance the economic productivity. This paper aims to contribute to this overlooked but important research line. There are two objectives of this paper. Semantically, this paper comprehensively reviews the social infrastructure literature from various aspects and applications. Then, it reviews nine journal papers and one conference paper in terms of ontology, epistemology and methodology. The preliminary finding reveals that ontological subjectivism, epistemological interpretivism, and qualitative analysis have dominated the social infrastructure domain. Last sections of this paper discuss the limitations and future research directions. The outcome can be used to improve general understanding of the social infrastructure projects.
\end{abstract}

Keywords: social infrastructure, philosophical review, construction industry

\section{Introduction}

Construction industry basically deals with the construction and erection of a building and structure. The nature of industry is dynamic due to the fact that the uniqueness of end product is built on various ground conditions. Uncertainties are foreseeable and unavoidable. Because the industry changes the natural landscape of earth, it provides human beings with better living conditions. Therefore, the industry is inevitably perceived as one of the most significant industries in the economy of any nation. In this sense, construction industry has been the focus of the literature for more than a decade. Researches conducted within construction domain generally fall into addressing either particular or general issues (Hanisch and Wald, 2011). This paper is materialised on the ground that addressing the issue of particular is a solution to the dynamic nature of knowledge. Social infrastructure projects (SIP) is a case in point.

The rationale of this paper is built on the fact that SIP is needed to serve the new community and thereby enhance the quality, image and desirability of a new place as well as its commercial value (BPF, 2010). This view is reinforced by Teriman et al. (2011) who perceive that SIP meets the basic needs of communities and enhances the quality of life, equity, stability and social well being. The authors further posit that SIP and

Copyright (C) 2012 Wai Soon Han, Aminah Md Yusof, Tey Kim Hai and Syuhaida Ismail. This is an open access article distributed under the Creative Commons Attribution License unported 3.0, which permits unrestricted use, distribution, and reproduction in any medium, provided that original work is properly cited. Contact author: Wai Soon Han E-mail: shwai2@live.utm.my 
sustainable development are two interrelated concepts. Additionally, SIP will constitute a catalytic to other sector for a nation. Malaysia tourism is a case in point where the number of foreign patient seeking treatment in the country generated about US\$27 million in 2004 and the figure is expected to stand at US\$56 million a year in national earning by 2010 (ESCAP, 2007). Despite the highlighted significances, there has been limited on SIP.

As such, the emphasis of this paper is placed upon bridging the research gap. Then, the research moves a step further by examining the philosophical stances of ten selected journal and conference papers. Addressing the philosophical stances is not uncommon within the domain of construction management. However, to the knowledge of authors, although this paper presents preliminary result, it serves as the first attempt within the SIP domain. In the conclusion, the dominant line in terms of ontological, epistemological and methodological is presented. The limitations are presented in order to further enhance the originality of this paper. Lastly, future research directions are also suggested.

\section{Literature Review}

\section{Social Infrastructure}

The notion of social infrastructure has emerged over the last decade. Heaps of researches have been conducted in India; Australia; British; and Hong Kong, China. The domain has emerged mainly due to the fact that public infrastructure is the most apparent form of construction which interests the society at large (Duffield, 2001). Therefore, this subsection thoroughly reviews the social infrastructure across literature.

Infrastructure is defined as the productive capital structures that underpin the economy and society and contribute over time to the achievement of its economic and social goals
(Johnson et al., 1995). In this regard, economic infrastructure and social infrastructure have consequently emerged. Although both economic and social infrastructures have significant social impacts on individuals, communities, and the general public at large in terms of practicality, a distinction between both infrastructures based on their social impact is ambiguous and difficult to establish (Gilmour et al., 2010). Likewise, SIP is services delivered by welfare agencies, more commonly known as "human services". The outcome of human service is more difficult to predict as they are dependent on the way staff interpret policies (a factor less significant in economic infrastructure projects) as well as how recipients react to them (Hasenfield, 1992). As a result, as the SIP domain expands rapidly, the need to differentiate both infrastructures increases. The genesis of this paper stems from this need. Argy et al. (1999) further differentiate social infrastructures into hard social infrastructure (e.g. hospitals) and soft infrastructure (e.g. social security). This paper, however, only focuses on social infrastructure alone.

Social infrastructure may also involve a wider range of partners including in most cases various government agencies, private companies and non-profit organizations together with a selection of user groups, freelance scientists, independent consultants as well as academic research institutes (Oppen et al., 2005). Although SIP involves welfare agencies and generally smaller scale as compared to economic infrastructure, SIP is as complex and dynamic as generic construction projects. This is due to the fact that the post construction and maintenance stage involve an ongoing involvement with the community (Jefferies and McGeorge, 2009). Wai et al. (2011) concluded SIP as the provision of infrastructure particularly with respect to three aspects namely well social value defined, non-profit defined provision and generally procured via Public Private Partnership (PPP) contracting method. 
Previous studies have focused mainly on examining the SIP within the PPP contracting method (Jefferies, 2006; Jefferies, and McGeorge, 2008; Jefferies and McGeorge, 2009; Syuhaida and Aminah, 2009; Hellowell and Pollack, 2011; Gilmour et al., 2010). PPP is the wider term used to indicate the specific partnership between public and private sector. PPP can be further grouped into Build Own Operate Transfer (BOOT) and the emerging Private Financial Initiative (PFI). In this regard, Jefferies et al. (2002) and Jefferies (2006) specifically address the SIP in BOOT contracting method. The authors draw a list of critical success factors from respective case study. Meanwhile, a study conducted by Syuhaida and Aminah (2009) investigate the features and characteristics of infrastructure that is suitable to be provided via PFI in a Malaysian construction industry context and the result highlights SIP as one. Another study conducted by Hellowell and Pollack (2011) outlines and critiques the main fiscal and economic rationale in an England's construction industry context with particular reference to health service sector.

Having reviewed the literature based on contracting method, more particular context SIP research was found. Some researches are conducted to address the very specific sector such as stadium (Jefferies et al. 2001; Jefferies et al. 2002; Jefferies, 2010), housing renewal (Gilmour et al. 2010), hospital (Jefferies et al., 2006; Love et al., 2011) and school (Love et al., 2011). Although the emphasis of the researches is only placed upon specific structure, the structure is understandable as SIP. Of the researches conducted, it is important to note that the SIP is difficult to be separated from PPP. Although the trend has emerged in this way, the SIP domain is facing the probability of saturation in context. To avoid saturation in context, the next subsection presents a literature review on philosophical stance of research.

\section{Philosophical Review of Research}

Most researches either intentionally or unintentionally abandon the philosophical stances in their discussion respectively (Maanen et al., 2007; Biedenbach \& Müller, 2011). In relation to this, Dainty (2007) and Schwandt (2001) posit that it is necessary to discuss the philosophical stance of research and methods adopted. Basically, as far as the philosophical stance is concerned, McCallin (2003) suggests that the paradigm of inquiry should be considered early in the research process. It is not uncommon that research paradigms usually require the consideration in the aspect of ontology, epistemology and methodology. Most researches only discuss the methodological aspect while ignoring the ontological and epistemological aspect of their research respectively. Ontology is a theory concerned with what exists and how it exists, while epistemology is the theory that is concerned with the relationship between the knower and what can be known (Guba and Lincoln, 1994).

Within the context of project management, Söderlund (2010) first suggests the idea of applying pluralism. The author draws upon the emphasis in Knudsen (2003) that an area with too little pluralism can be easily caught in a specialization trap, while area with too much pluralism will be easily caught in a fragmentation trap. Dainty (2007) further proposes that methodological pluralism should be embraced in the context of construction management. The idea has emerged due to the fact that the industry per se is dynamic and complex in nature, leading to the dispute between the issue of particular and general. Because positivism has dominated the research line (Dainty, 2007), Guba and Loncoln (1994) identify several critiques of positivism, namely disjunction in local contexts, inapplicability of general data to individual cases and exclusion of the discovery dimension in inquiry. 
Biedenbach and Muller (2010) found that ontological subjectivism, epistemological interpretism with a preference for qualitative methods have dominated the research paradigms in project management. Subjectivism is concerned with human beings as acting in the world through sense making and context modifying which is confronted to objectivism that is concerned with motivation of providing human beings with law-like and rational knowledge that will help them function successfully in external world (Huizing, 2007). Meanwhile, the interpretivism stresses the necessity that researcher understands the difference between humans and addresses the complexity of social actions (Saunders et al., 2007). The overall findings of this particular paper suggest that it is necessary to understand the management world rather than creating the knowledge applicable to all types of project.

\section{Research Methodology}

This paper adopts systematic samplings (Saunders et al., 2007). Biedenbach and Muller (2010) and Chan et al., (2009) demonstrate the systematic samplings by reviewing the practices from selected domain with particular regard to journals and conference papers for a specific period of time. This paper adopts the same research methods. Because this paper is a partial work of an on-going doctoral study, the overall objective of this paper is to present a preliminary result of analysis of ten selected papers in the aspect of philosophical stance. The selection of journals and conference papers is mainly based on the top quality journal publishers, which include: (1) American Society of Civil Engineers (ASCE); (2) Science Direct; (3) Emerald; (4) SAGE; and (5) various online sources. The keyword for journals and conference papers selection is "social infrastructure". To maintain validity, two selection criteria were set for retrieving social infrastructure papers, which are: (1) the title of the journals and conference papers were scanned with the keyword. Altogether, there were 17 social infrastructure papers that contained the keyword in their paper's title, which is "social infrastructure" and (2) seven social infrastructure papers were taken out because they were not in construction industry or construction management context. The selection criteria are essential to maintain their reality (Taylor et al., 2011). Altogether, there were 10 social infrastructures papers that fitted well the selection criteria and were selected for further analysis. The papers were assessed through three aspects including ontology, epistemology, and methodology. For ontology aspect, it consists of subjectivism, objectivism and pragmatism (Saunders et al., 2007). For epistemology aspect, it consists of positivism, interpretivism, and realism (Bryman and Bell, 2007). Lastly, for methodology aspect, there are quantitative and quality analyses, respectively.

\section{Result and Discussion}

This section presents the result of the analysis of the aforementioned papers in the philosophical stance aspect. Table 1.0 and Table 2.0 portray the selected journal and conference papers and the result of analysis respectively. As shown, nine journal papers and one conference paper are selected for further analysis. Of the ten papers, nine papers are based on ontological subjectivism oriented and nine papers are based on epistemological interpretivism. Only one paper is based on objectivism and positivism, respectively. In the methodology aspect of selected papers, six papers are conducted through qualitative research methodology adopting case study, three papers are based on qualitative research methodology adopting interview and one paper is based on quantitative research methodology adopting questionnaire. There is surprisingly no single paper conducted based on pragmatism. In fact, 17 papers have survived the keyword, "social infrastructure", scanning process in their title. Only a few number of papers are found through the literature title search applied through various sources. 
In terms of percentages, subjectivism recorded 90 percent, followed by 90 percent interpretivism, and 60 percent assessed papers which are qualitative research adopting case study approach. Therefore, this paper claims that the subjectivism is the dominant ontology; epistemological interpretivism is the dominant epistemological and qualitative research adopting case study is the dominant methodology in SIP domain. Biedenbach and Muller (2010) echo the finding of this paper by reporting the same result in generic project management research. The authors report the trend based on an analysis performed on around 100 selected conference papers of the International Research Network on Organizing by Projects (IRNOP) for the time frame of 15 years. However, Morgan (2007) postulates that the same community of researchers of an area of specialization tends to share the same belief in terms of paradigms. In this regard, the results are subjected to bias because the data were selected from the same research community.

The literature review performed on SIP domain reveals some facts. Previous studies on SIP generally tied to economic development of a nation or more specifically, tied to PPP. This is maybe due to the fact that the nature of construction management research is itself elusive. Consequently, alternative contracting method to effectively procure SIP is perceived to have high impact and commercial value. The value of SIP domain is that social infrastructure is one of the main criteria to enhance the economy productivity. Therefore, an alternative way in procuring SIP will be the main focus in research world. This paper also finds that countries such as Australia, Hong Kong, China and United Kingdom are the pioneering countries in the domain of SIP. The limitations of this paper are presented in the next section.

\section{Limitation}

The limitation lies in the fact that this paper only presents partially completed work of an on-going research at the University of Technology Malaysia towards an award of a doctoral degree. As such, this paper theoretically reviews the SIP and reports a preliminary result that highlights its philosophical trend. In this sense, the main limitation of this paper is that the data collection was meticulously planned in advance. The selection criteria are limited to scanning the title of the journals and conference papers with the keyword, which is "social infrastructure". Despite the fact that the scanning process eliminates many papers that are closely related to the social infrastructure topic, it is adequate for the purposes of this paper.

\section{Significance of Research}

This paper contributes to the body of knowledge by providing a comprehensive literature review about SIP. Moreover, it reviews ten selected SIP papers in the aspects of ontology, epistemology and methodology which is not found in any other previous work. This paper also draws attention to the SIP which is usually overlooked in building a sustainable community. This paper presents a preliminary result of SIP, which attracts less attention throughout the literature. This further justifies the contribution of this paper.

\section{Conclusions and Recommendations}

Infrastructures are broadly related to basic structures that flow the goods and services between different people and places (Teriman, 2011). There are economic infrastructure and social infrastructure. Social infrastructure usually attracts less attention among the community. 
However, it is of huge importance to build a sustainability community as it stimulates the production of social cohesion. The existing SIP research is minimal compared to that on economic infrastructure. As a point of departure, this paper addresses the research gap and presents a preliminary result revealing that the dominance line is ontological subjectivism, epistemological interpretivism and qualitative research adopting case study. The philosophical stance of research is important in the sense that it contains assumptions about the way the researcher views the world. These are important criteria that underpinned the research strategy and method. This also differentiates the social science research and engineering research. In fact, not only will the research methodology differ considerably, but so will the limitation, significance as well as contribution of the research differ simultaneously. As such, understanding the philosophical trend of research is of importance to researchers because the choices of methodology should be based on the researcher's philosophical stance. Also, this paper shall serve as a pioneer move in acknowledging the importance of philosophical background of research by performing a literature review and highlighting the dominance line in the context of SIP. Likewise, this paper is in line with the current movement of "rethinking project management".

Finally, it is crucial that future research focuses on addressing the pluralism of social infrastructure rather than continue linking SIP with PPP. In addition, it is also intrinsic that future research focus on soft dimension of social infrastructure which includes health, education, employment and training and public safety. Moreover, further research could continue reviewing the SIP papers to provide sufficient evidence for trend identification. Lastly, as an increasing trend of studying the social infrastructure is observed, it is believed that social infrastructure research will have significant impact in enhancing the competitiveness of a nation.

Table 1: Details of Selected Papers

\begin{tabular}{|l|l|l|}
\hline No & \multicolumn{1}{|c|}{ Source } & \multicolumn{1}{|c|}{ Authors (Year) } \\
\hline 1 & Accident Analysis and Prevention & $\begin{array}{l}\text { Love, PED., Lopez, R., Edwards, D. and } \\
\text { Goh, YM. (2011) }\end{array}$ \\
\hline 2 & $\begin{array}{l}\text { The Australian Journal of Public } \\
\text { Administration }\end{array}$ & Hellowell, M. and Pollack, AM. (2009) \\
\hline 3 & Computer Society of India & Mital, KM. and Mital, V. (2006) \\
\hline 4 & Environment and Urbanization & Uduku, NO. (1994) \\
\hline 5 & Environment and Urbanization & Yahya, SS. (2008) \\
\hline 6 & $\begin{array}{l}\text { Engineering, Construction and } \\
\text { Architectural Management }\end{array}$ & Jefferies, M. and McGeorge, WD. (2009) \\
\hline 7 & Journal of Construction Procurement & Jefferies, M. and McGeorge, WD. (2008) \\
\hline 8 & $\begin{array}{l}\text { Journal of Financial Management of } \\
\text { Property and Construction }\end{array}$ & $\begin{array}{l}\text { Gilmour, T., Wiesel, I. and Pinnegar, S. } \\
(2010)\end{array}$ \\
\hline 9 & $\begin{array}{l}\text { Proceedings of the Business and Social } \\
\text { Science Research }\end{array}$ & $\begin{array}{l}\text { Teriman, S., Yigitcanlar, T. and Mayere, S. } \\
(2011)\end{array}$ \\
\hline 10 & The World Bank Economic Review & Pradhan, M. and Rawlings, LB. (2002) \\
\hline
\end{tabular}


Table 2: Result of Analysis - Philosophical Trends

\begin{tabular}{|l|l|l|l|}
\hline Paper No & \multicolumn{1}{|c|}{ Ontological } & Epistemological & Methodology \\
\hline 1 & Subjectivism & Interpretivism & Qualitative research adopting case study \\
\hline 2 & Subjectivism & Interpretivism & Qualitative research adopting case study \\
\hline 3 & Subjectivism & Interpretivism & Qualitative research adopting case study \\
\hline 4 & Subjectivism & Interpretivism & Qualitative research adopting case study \\
\hline 5 & Subjectivism & Interpretivism & Qualitative research adopting case study \\
\hline 6 & Subjectivism & Interpretivism & Qualitative research adopting interview \\
\hline 7 & Subjectivism & Interpretivism & Qualitative research adopting interview \\
\hline 8 & Subjectivism & Interpretivism & Qualitative research adopting interview \\
\hline 9 & Subjectivism & Interpretivism & Qualitative research adopting case study \\
\hline 10 & Objectivism & Positivism & $\begin{array}{l}\text { Quantitative research adopting } \\
\text { questionnaire }\end{array}$ \\
\hline
\end{tabular}

\section{Acknowledgment}

The research was supported by the Grant for Research University (GUP) of the University of Technology Malaysia, Johor for research funding under Cost Centre No. Q.K130000.7140.00H47. The authors of this paper would like to acknowledge the assistance provided by the Ministry of Higher Education (MOHE); University of Technology Malaysia (UTM); Research Management Center (RMC); and Innovative Construction Research Alliance (ICON) in making this paper a reality.

\section{References}

Argy, F., Lindfield, M., Stimson, B. \& Hollingsworth, P. (1999). 'Infrastructure and Economic Development,' CEDA Information Paper No. 60, Committee for Economic Development of Australia, Melbourne.

Biedenbach, T. \& Müller, R. (2011). "Paradigms in Project Management Research: Examples From 15 Years of IRNOP
Conferences," International Journal of Managing Projects in Business, 4, 82-104.

BPF, (2010). 'Planning for Social Infrastructure in Development Projects: a Guide to Tackling the Key Challenges,' [Online]. British Property Federation. [Retrieved October 16, 2011], Http://Www.Bpf.Org.Uk/En/Files/Bpf_Ducu ments/Social_Infratructure_Report_Final.Pdf

Bryman, A. \& Bell, E. (2007). Business Research Methods, Oxford, University Press, Oxford.

Chan, A. P. C., Chan, D. W. M. \& Yeung, J. F. Y. (2009). "Overview of the Application of Fuzzy Techniques in Construction Management Research," Journal of Construtcion Engineering and Management, 135(11), 1241-1252.

Dainty, A. (2007). A Call for Methodological Pluralism in Built Environment Research, Proceedings of the Third Scottish Conference for Postgraduate Researchers of the Built 
Environment, Glasgow Caledonian University, November 20-22, 1-10, Probe.

Duffield, C. F. (2001). 'An Evaluation Framework for Privately Funded Infrastructure Projects in Australia,' Unpublished Phd Thesis, Department of Civil and Environmental Engineering, University of Melbourne, Melbourne.

ESCAP, (2007). "Medical Travel in Asia and the Pacific Challenges and Opportunities," [Online]. Economic and Social Commission for Asia and the Pacific. [Retrieved October 20, 2011], Http://Www.Unescap.Org/ESID/Hds/Lastes tadd/Medicaltourismreport09.Pdf

Gilmour, T., Wiesel, I., Pinnegar, S. \& Loosemore, M. (2010). "Social Infrastructure Partnerships: a Firm Rock in a Storm?," Journal of Financial Management of Property and Construction, 15(3), 247-259.

Guba, E. G. \& Lincoln, Y. S. (1994). Competing Paradigms in Qualitative Research, Handbook of Qualitative Research, Denzin, NK. and Lincoln, YS. (Ed), Thousand Oaks: Sage Publications, Pp. 105-117.

Hanisch, B. \& Wald, A. (2011). “A Project Management Research Framework Integrating Multiple Theoretical Perspectives and Influencing Factors," Project Management Journal, 42(3), 4-22.

Hasenfield, Y. (1992). Human Services as Complex Organizations. Sage, Newbury Park, CA. Pp. 4.

Hellowell, M. \& Pollack, A. M. (2010). “Do Ppps in Social Infrastructure Enhance the Public Interest? Evidence from England's National Health Service," The Australian Journal of Public Administration, 69(1S), S23S34.

Huizing, A. (2007). "The Value of a Rose: Rising Above Objectivism and Subjectivism," [Online]. University of Amsterdam, Netherlands. Sprouts: Working Papers on
Information Systems, 7(11). [Retrieved August 20, 2011],

Http://Sprouts.Aisnet.Org/7-11

Jefferies, M. (2006). "Critical Success Factors of Public Private Sector Partnerships: a Case Study of the Sydney Superdome," Engineering, Construction and Architectural Management, 13, 451-462.

Jefferies, M. C., Cook, M. J. \& Rowlinson S. (2001). "The BOOT Approach for Stadium Australia: Reflecting on the Critical Factors for Success," Proceedings of the CIB World Building Congress, New Zealand.

Jefferies, M. C., Mcgeorge, D., Chen, S. E. \& Cadman, K. (2006). "Sustainable Procurement: a Contemporary View on Australian Public Private Partnerships (Ppps)," British University of Dubai, Dubai.

Jefferies, M., Gameson, R. \& Rowlinson, S. (2002). "Critical Success Factors of the BOOT Procurement System: Reflections from the Stadium Australia Case Study," Engineering, Construction and Architectural Management, 9(4) 352-361.

Jefferies, M. \& Mcgeorge, D. (2008). “PublicPrivate Partnerships: a Critical Review of Risk Management in Australian Social Infrastructure Projects," Journal of Construction Procurement, 14(1), 66-80. Http://Hdl.Handle.Net/1959.13/41633.

Jefferies, M. \& Mcgeorge, W. D. (2009). “Using Public-Private Partnerships (Ppps) to Procure Social Infrastructure in Australia," Engineering, Construction and Architectural Management, 16, 415-437.

Johnson, S., Gostelow, P., Jones, E. \& Fourikis, R. (1995). 'Engineering \& Social - an Australian Perspective,' Pymble: Harper Educational Publishers, Australia.

Knudsen, C. (2003). Pluralism, Scientific Progress, and the Structure of Organisation Theory, Oxford University Press Handbook on Organisation Theory, Tsoukas, H. and 
Knudsen, C. (Ed), Oxford: Oxford University Press, 262-288.

Lewis, P., Thornhill, A. \& Saunders, M. (2007). Research Methods for Business Students, 4th Ed., Pearson Education, Harlow.

Love, P. E. D., Lopez, R., Edwards, D. J. \& Goh, Y. M. (2011). "Error Begat Error: Design Error Analysis and Prevention in Social Infrastructure Projects," [In Press] Accident Analysis and Prevention.

Maanen, J. V., Sorensen, J. B. \& Mitchell, T. R. (2007). "The Interplay between Theory and Method," Academy of Management Review, 32(4), 1145-1154.

Mccallin, A. M. (2003). "Designing a Grounded Theory Study: Some Practicalities," Nursing in Critical Care, 8(5), 203-208.

Mital, K. M. \& Mital, V. (2006). "Public Private Partnership and Social Infrastructure, Foundation of E-Government," Agarwal, A. and Ramana, V. (Ed), Computer Society of India.

Morgan, D. L. (2007). "Paradigms Lost and Pragmatism Regained: Methodological Implications of Combining Qualitative and Quantitative Methods," Journal of Mixed Methods Research, 1, 48-76.

Oppen, M., Sack, D. \& Wegener, A. (2005). Germany: Private-Public Partnerships in Personal Social Services. New Directions in a Corporatist Environment. in G. Hodge and C. Greve (Eds), the Challenge of Public-Private Partnerships: Learning from International Experience, Edward Elgar, Cheltenham, Pp.269-89.

Pradhan, M. \& Rawlings, L. B. (2002). "The Impact and Targeting of Social Infrastructure Investments: Lessons from the Nicaraguan Social Fund," The World Bank Economic Review, 16(2), 275-295.
Schwandlt, T. A. (2001). 'Dictionary of Qualitative Inquiry,' Second Edition, London: Sage Publications.

Söderlund, J. (2011). "Pluralism in Project Management: Navigating the Crossroads of Specialization and Fragmentation," International Journal of Management Reviews, 13(2), 153-176.

Syuhaida I. \& Aminah Md. Y. (2009). "The Provision of Infrastructure Via Private Financial Initiative," Theoretical and Empirical Researches in Urban Management, 4(1S), 76-86. Http://Um.Ase.Ro/No1s/7.Pdf.

Taylor, J. E., Dossick, C. S. \& Garvin, M. (2011). "Meeting the Burden of Proof with CaseStudy Research," Journal of Construction Engineering and Management, 303-311.

Teriman, S. Yigitcanlar, T. \& Mayere, S. (2011). "Social Infrastructure Planning and Sustainable Community: Example from South East Queensland, Australia," Proceedings of the Business and Social Science Research Conference, World Business Institute Australia, Novotel, World Trade Centre, Dubai, 1-12.

Uduku, N. O. (1994). "Promoting Community Based Approaches to Social Infrastructure Provision in Urban Areas in Nigeria," Environment and Urbanization, 6(2), 57-78.

Wai, S. H., Yusof, M. d., AMINAH \& Ismail, SYUHAIDA (2011). 'Relationship Framework for Social Infrastructure Success Determinants and Criteria,' Proceedings of the International Conference on Quality in Research, ISSN114-1284, 4-6 July 2011, Bali, Indonesia, 566-573.

Yahya, S. S. (2008). "Financing Social Infrastructure and Addressing Poverty Through Wakf Endowments: Experience from Kenya and Tanzania," Environment and Urbanization, 20, 427-444. 